\title{
Temperature correlates with annual changes in Hematodinium perezi prevalence in blue crab Callinectes sapidus in Florida, USA
}

\author{
Ryan Gandy ${ }^{1, *}$, Eric J. Schott ${ }^{2}$, Claire Crowley ${ }^{1}$, Erin H. Leone ${ }^{3}$ \\ ${ }^{1}$ Florida Fish and Wildlife Conservation Commission, Fish and Wildlife Research Institute, 100 Eighth Avenue SE, \\ St. Petersburg, FL 33701-5020, USA \\ ${ }^{2}$ Institute of Marine and Environmental Technology, University of Maryland Center for Environmental Science, \\ 701 East Pratt St., Baltimore, MD 21202, USA \\ ${ }^{3}$ Florida Fish and Wildlife Conservation Commission, Fish and Wildlife Research Institute, \\ Center for Biostatistics and Modeling, 1105 SW Williston Rd, Gainesville, FL 32601, USA
}

\begin{abstract}
Blue crabs Callinectes sapidus were monitored biannually throughout Florida, USA, for 2 yr using a highly sensitive, quantitative polymerase chain reaction (qPCR) to determine the spatial and temporal changes in prevalence and intensity of Hematodinium perezi infections during drought years. Despite persistent drought conditions, H. perezi infections were not universally found. Overall prevalence was $25.3 \%$ (95\% CI: 22.8-28.1\%) in 1066 crabs sampled from 6 locations (Jacksonville, Ormond Beach, Everglades City, Tampa Bay, Steinhatchee, and Panama City) from 2011 to 2012. Presence of $H$. perezi was consistently highest in winter season samples, ranging from $4.2-51.1 \%$ (3 locations) in 2011, to $32-83 \%$ (5 locations) in 2012. The highest prevalence and intensities were observed in the winter samples from Everglades City. Previous studies have found that the prevalence of $H$. perezi in C. sapidus in temperate regions of the US East Coast shows seasonal peaks in early winter in Maryland and South Carolina and in fall and spring in Georgia. The seasonality of infections in the subtropical waters of Florida reinforces the concept that temperature is a strong factor that may override other drivers, such as drought. Seasonal $H$. perezi infections in Florida appear to be triggered by the parasite responding to an optimal temperature during the annual rise from the low temperature of winter when salinity is elevated. However, salinity alone is not sufficient to trigger an increase in prevalence of $H$. perezi in Florida.
\end{abstract}

KEY WORDS: Crustacean $\cdot$ Disease $\cdot$ Parasite $\cdot$ Drought $\cdot$ Environment

\section{INTRODUCTION}

In temperate and subtropical climatic zones of the USA, the blue crab Callinectes sapidus is subject to infection by a lethal parasitic dinoflagellate of the genus Hematodinium (Messick \& Shields 2000, Small et al. 2012). In Florida and adjacent waters, Hematodinium sp. infections have been documented in blue crab, spider crab Libinia emarginata, the xanthid crab Neopanope sayi, stone crab Menippe merce-

\footnotetext{
*Corresponding author: ryan.gandy@myfwc.com
}

naria, and lesser blue crab C. similis (Messick \& Shields 2000, Gruebl et al. 2002, Sheppard et al. 2003). Although a variety of related parasites within the genus infect Crustacea worldwide (Stentiford \& Shields 2005), it has recently been confirmed that the Hematodinium species infecting blue crabs along the US Atlantic and Gulf coasts is H. perezi (Small et al. 2012, Pagenkopp Lohan et al. 2013), resulting in a high likelihood that pre-2012 studies on Hematodinium sp. were describing $H$. perezi.

() The authors 2015. Open Access under Creative Commons by Attribution Licence. Use, distribution and reproduction are unrestricted. Authors and original publication must be credited. 
Prevalence of $H$. perezi in C. sapidus varies seasonally throughout the temperate zone of the US Atlantic coast, as documented in coastal bay systems of the mid-Atlantic and South Atlantic Bight (SAB). The reported annual fluctuations in prevalence and intensity (analogous to parasite load) in the blue crab are congruent with reports of Hematodinium sp. infections in other temperate and boreal crustacean hosts worldwide, such as the Norway lobster Nephrops norvegicus (Stentiford et al. 2001). The comprehensive study of Messick \& Shields (2000) included only 1 date and Florida location (July, Fort Pierce), and Newman \& Johnson (1975) reported Hematodinium sp. at an unspecified location and date in Florida in 1968-1969. Despite the lack of samples collected from Florida in previous studies, there appears to be potential for high infection rates in Florida and adjacent coastal waters of Georgia where Hematodinium sp. was reported at a prevalence of more than $30 \%$ of crabs sampled (Messick \& Shields 2000, Gruebl et al. 2002). Our understanding of the relationships between seasonal peaks in intensity, latitude, and environmental factors, such as temperature and salinity, which have direct impacts on the parasite and its host, is incomplete, especially as they pertain to subtropical regions of Florida.

Positive correlations between freshwater inputs and blue crab fisheries landings along Florida's Gulf and Atlantic coasts are well documented (Wilber 1994, Guillory et al. 2001, Cooper et al. 2011, VanderKooy 2013). The role of drought in increasing the incidence of disease-causing Hematodinium sp. and how it contributes to reduced blue crab productivity during drought years is less clear. Drought conditions result in decreased freshwater input and increased salinity in estuaries and tidal tributaries, which are often correlated with Hematodinium sp. outbreaks and declines in blue crab abundance. Naturally occurring infections of Hematodinium sp. in C. sapidus are prevalent only in high-salinity waters, i.e. $>18$ PSU (Messick \& Shields 2000, Stentiford \& Shields 2005, Parmenter et al. 2013), where they progress rapidly. Alternatively, salinities below 15 PSU appear to have negative impacts on the parasite (Newman \& Johnson 1975, Messick \& Shields 2000, Gruebl et al. 2002, Coffey et al. 2012). This relationship with salinity was first evidenced during an extended drought in Georgia which corresponded to a collapse of the blue crab fishery concurrent with an outbreak of Hematodinium sp. (Lee \& Frischer 2004). In South Carolina, a drought was similarly correlated with a decrease in blue crab fishery landings and an increase in the presence of Hematodinium sp. (Par- menter et al. 2013). In response to the clear relationship between Hematodinium sp. infections and drought along the $\mathrm{SAB}$, it was considered important to investigate the seasonal prevalence and intensity of this pathogen during drought years in Florida.

The 3 major blue crab-producing regions of Florida (northeast, northwest, and southwest) were in various stages of drought from 2006 through the beginning of winter 2010-2011 (NOAA National Climate Data Center). This regionwide drought provided an opportunity to investigate the statewide spatial and temporal distribution of the prevalence and intensity of the parasite under conditions that may promote infections in blue crab. In the present study, infections were monitored biannually for 2 yr (2011 to 2012) at northern, central, and southern sites along both coasts. Regionally specific understanding of the epizootiology of the parasite in relation to abiotic factors such as temperature, salinity, and drought index was sought to assess the threat of parasitism to the blue crab fishery in Florida during drought years. Our findings provide the first assessment of the regional and seasonal distribution of the parasite in fished populations of blue crabs in Florida. This study recorded $H$. perezi prevalence in Florida where C. sapidus is active, fished year-round and does not exhibit a winter dormancy period, as it does in temperate regions.

\section{MATERIALS AND METHODS}

\section{Blue crab and water quality data collection}

Through cooperative efforts with Florida commercial blue-crab fishermen, Florida Fish and Wildlife Conservation Commission, Fish and Wildlife Research Institute (FWC-FWRI) staff obtained blue crabs from 6 locations: Jacksonville (JA) $30^{\circ} 33.45^{\prime} \mathrm{N}, 81^{\circ} 36.35^{\prime} \mathrm{W}$; Ormond Beach (OB) $29^{\circ} 24.48^{\prime} \mathrm{N}, 81^{\circ} 5.27^{\prime} \mathrm{W}$; Everglades City (EC) $25^{\circ} 52.01^{\prime} \mathrm{N}, 81^{\circ} 32.07^{\prime} \mathrm{W}$; Tampa Bay (TB) $27^{\circ} 41.48^{\prime} \mathrm{N}, \quad 82^{\circ} 27.27^{\prime} \mathrm{W}$; Steinhatchee (ST) $29^{\circ} 40.24^{\prime} \mathrm{N}, 83^{\circ} 32.47^{\prime} \mathrm{W}$; and Panama City (PC) $30^{\circ} 15.49^{\prime} \mathrm{N}, 85^{\circ} 37.65^{\prime} \mathrm{W}$ (Fig. 1). Commercial crabpot sampling was conducted biannually at 4 locations (JA, OB, EC, TB) from the winter of 20102011 through the summer of 2012. Logistical constraints limited sampling to 2 periods for Steinhatchee (winter 2010-2011 and winter 2011-2012) and Panama City (winter 2011-2012 and summer 2012).

Depending on the season and local catch rates, 24 to 89 crabs were caught from each location and analyzed for Hematodinium sp. prevalence and intensity 


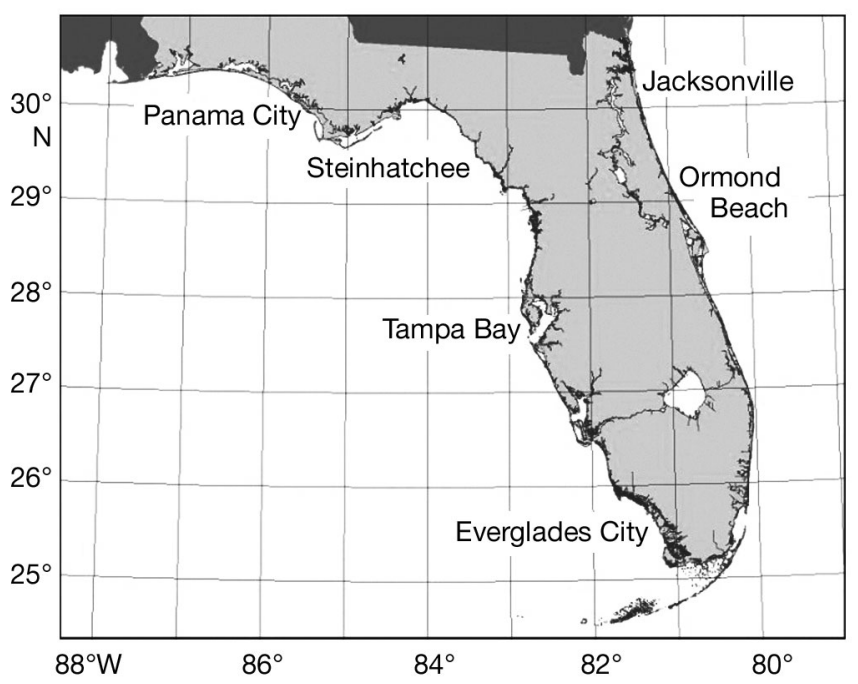

Fig. 1. Sampling locations for blue crabs Callinectes sapidus in Florida, USA

at the time of sampling. Temperature and salinity were recorded for each sampling site within a location using the YSI 650 MDS multiparameter display system. Crabs were transported live, at ambient temperature in wooden crates covered with burlap dampened with seawater, to the FWC-FWRI laboratory. The third and fourth walking legs were rinsed with $70 \%$ ethanol, removed, and immediately placed in a labeled Whirl-Pak bag (Nasco) and placed on ice. All samples were stored in a $-20^{\circ} \mathrm{C}$ freezer until DNA extractions were performed.

\section{DNA extraction and quantitative polymerase chain reaction (qPCR) assay}

The methodology used in this study was a highly sensitive qPCR (Nagle et al. 2009) that facilitated quantification of infection intensity from samples collected and archived over a 2 yr period. The legs were thawed and muscle tissue was dissected ( $50 \mathrm{mg})$ using a new razor blade that was then discarded. Depending on the amount of tissue available, 1 or both legs may have been used. Forceps and work area were cleaned with DNA Away (Molecular Bioproducts) between dissections to avoid cross-contamination. Muscle tissue was weighed and used for DNA extraction using the Gentra Puregene DNA Extraction Kit (Qiagen) following the manufacturer's instructions. DNA quantity and quality were assessed by spectrophotometry (Nanodrop, Thermo Scientific). Subsequent qPCR analysis was performed on a Stratagene Mx3000P Thermocycler (Agilent Technologies) using TaqMan Universal PCR Master Mix (Applied Biosys- tems, Life Technologies). Amplification of Hematodinium sp. DNA was conducted using $30 \mathrm{ng}$ of the extracted DNA using the primers, TaqMan ${ }^{\circledR}$ probe, and procedure of Nagle et al. (2009), which targets a 121nucleotide fragment of the small subunit ribosomal RNA (SSU rRNA) gene. All reactions were conducted in duplicate or triplicate, and each qPCR run included negative and positive controls, consisting of no DNA template and cloned target sequences, respectively. Quality control included performing inhibition tests (spiking each crab DNA sample with a known quantity of purified plasmid-borne target) to ensure that DNA was amplifiable. The number of $H$. perezi SSU gene copies was quantified in each qPCR reaction by comparison to a standard curve (10 to $10^{6}$ copies) of cloned $H$. perezi DNA (GenbankAF286023, Nagle et al. 2009) that was run in parallel on each plate. Based on the fraction of total DNA used in the qPCR reaction and the weight of the tissue from which it was extracted, the $H$. perezi intensity was calculated and expressed as the number of gene copies per $100 \mathrm{mg}$ of tissue. Species confirmation was accomplished by testing a subset of DNA samples that were positive by the Nagle assay and subsequently re-tested by a PCR assay that is specific for $H$. perezi (Hanif et al. 2013).

\section{Additional environmental data}

Drought indices for the Florida subregions were compiled from the National Oceanic and Atmospheric Administration's (NOAA) National Climate Data Center (www.ncdc.noaa.gov/cag/time-series/ us) and are presented in the format of the Palmer Drought Severity Index (PDSI). Water temperature data from NOAA's National Data Buoy Center (www.ndbc.noaa.gov) were compiled by selecting NOAA buoys nearest to each study location that reported continuous data for the study period: JA station, buoy FRDF1, 12 miles $(\sim 19 \mathrm{~km})$ northeast of station; OB station, buoy GTQF1, 25 miles $(\sim 40 \mathrm{~km})$ north; EC station, buoy LMRF1, 20 miles $(\sim 32 \mathrm{~km})$ southeast; TB station, buoy SAPF1, 10 miles $(\sim 16 \mathrm{~km})$ northwest; ST station, buoy APCF1, 90 miles $(\sim 144 \mathrm{~km})$ west; and PC station, buoy PACF1, 5 miles $(\sim 8 \mathrm{~km})$ southeast.

\section{Statistical analyses}

In order to compare infection rates between collection seasons, we performed a chi-squared analysis using SAS v9.3. Given the non-random nature of 


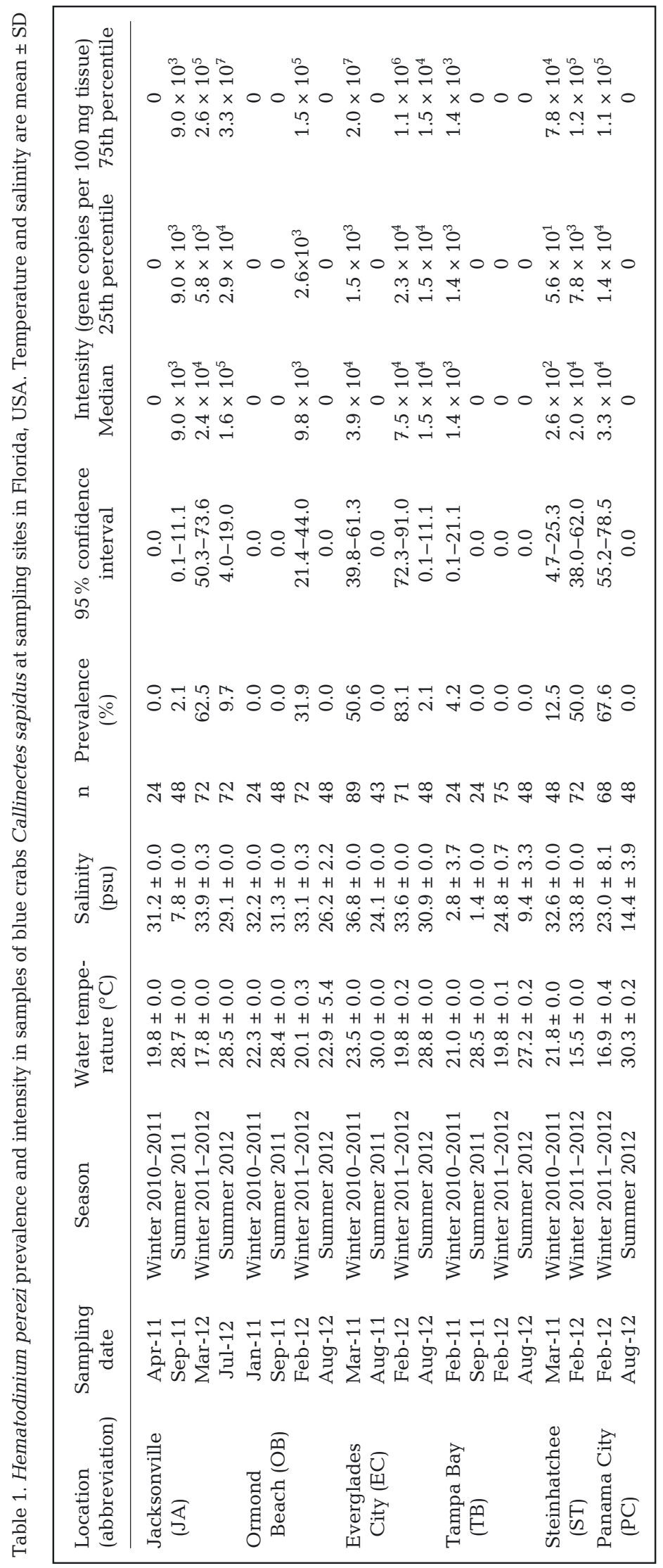

data collection, more sophisticated analyses would not be appropriate for this descriptive study. To quantify infection rates across locations and seasons, we calculated binomial proportions for each combination, as well as $95 \%$ confidence intervals.

\section{RESULTS}

The 2 yr period of biannual sampling resulted in the assessment of 1066 Callinectes sapidus from 6 locations on both coasts of Florida. Crabs ranging in size from 37 to $227 \mathrm{~mm}$ carapace width were captured by commercial means. Legal-size crabs $(>127 \mathrm{~mm}$ carapace width) represented $83.3 \%(\mathrm{n}=888)$ of the crabs captured and sampled. The small sample size and nonrandom nature of the data precluded the testing of drought index, salinity, and temperature beyond a descriptive level. There was a significant difference in infection rates across the 4 sampling seasons (Table 1, Fig. $2 ; \chi^{2}{ }_{3}=244.76, p<0.001$ ). Overall mean Hematodinium perezi prevalence was $40.9 \%$ at all 6 sites in winter samples (95\% CI: $37.0-44.8 \%, \mathrm{n}=639$ ) and $2.11 \%$ in summer samples (95\% CI: $1.0-4.0 \%, \mathrm{n}=427$ ) from 5 sites (JA, OB, EC, TB, PC). EC had the most consistent prevalence and median intensity during the winter sampling periods. In the winter of 2010-2011, the prevalence at EC was $50.6 \%$ (95\% CI: $39.8-61.3 \%)$, with a median intensity of $3.91 \times 10^{4}$ (gene copies per $100 \mathrm{mg}$ ), and in the winter of 2011-2012 prevalence was $83.1 \%$ (95\% CI: 72.3-91.0\%) with a median intensity of $7.45 \times 10^{4}$. JA had the highest median intensity $\left(1.59 \times 10^{5}\right.$, summer of 2012) of all regions sampled. Retesting a subset of positives with a species-specific PCR assay (Hanif et al. 2013) confirmed that the pathogen detected by the Nagle qPCR methodology was $H$. perezi.

The study began in the winter of 2010-2011 under moderate drought conditions at 5 locations (JA, OB, TB, ST, PC) and mild drought conditions at 1 location (EC; Fig. 3). Over the next 2 sampling periods (summer 2011 and winter 2011-2012), drought conditions either persisted $(\mathrm{EC}, \mathrm{TB})$ or worsened to severe drought (OB) or extreme drought (JA, ST, PC; Fig. 3). During the last sampling period, the summer of 2012, wetter conditions had re- 

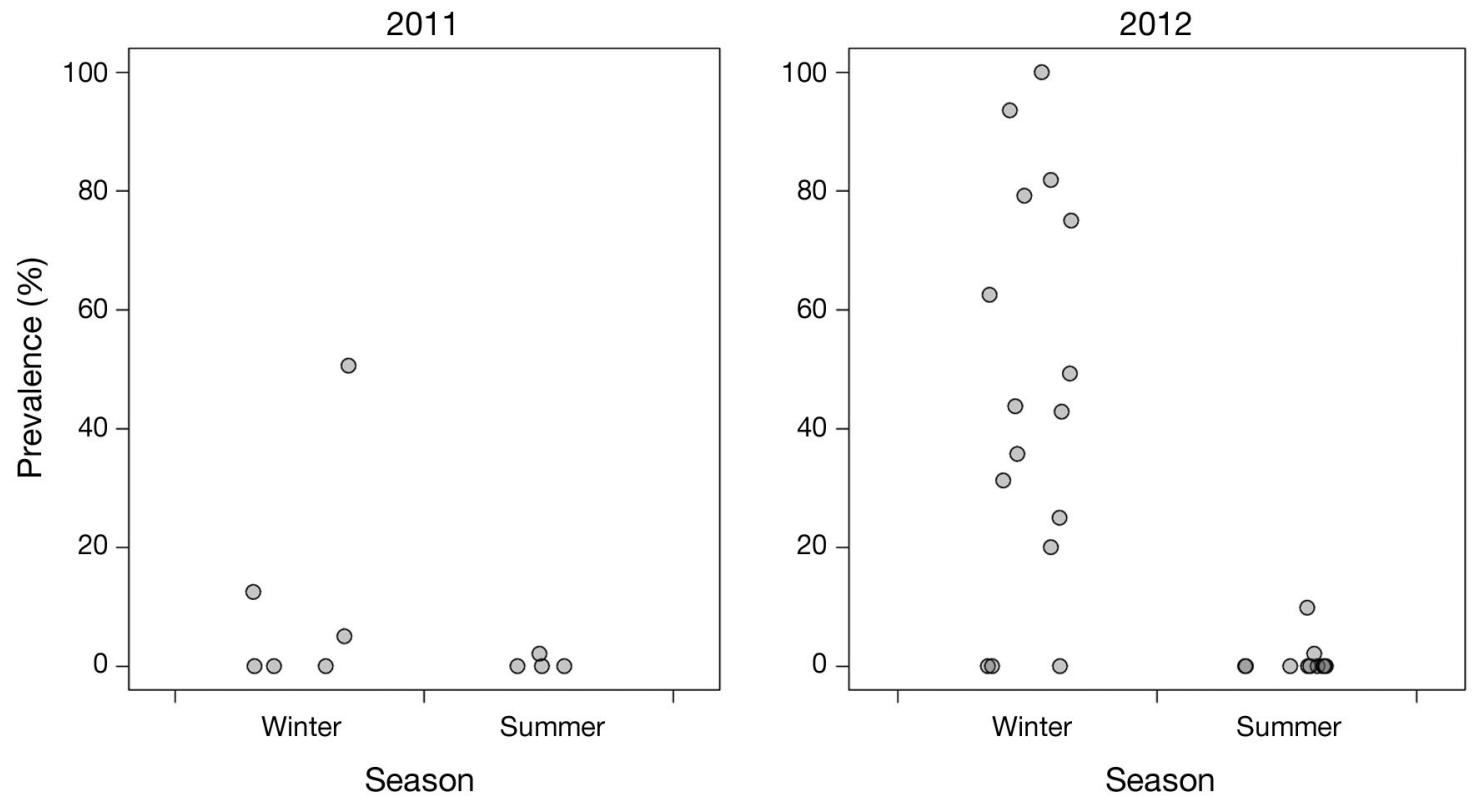

Fig. 2. Seasonal prevalence of Hematodinium perezi in samples of blue crabs Callinectes sapidus during 2011 and 2012

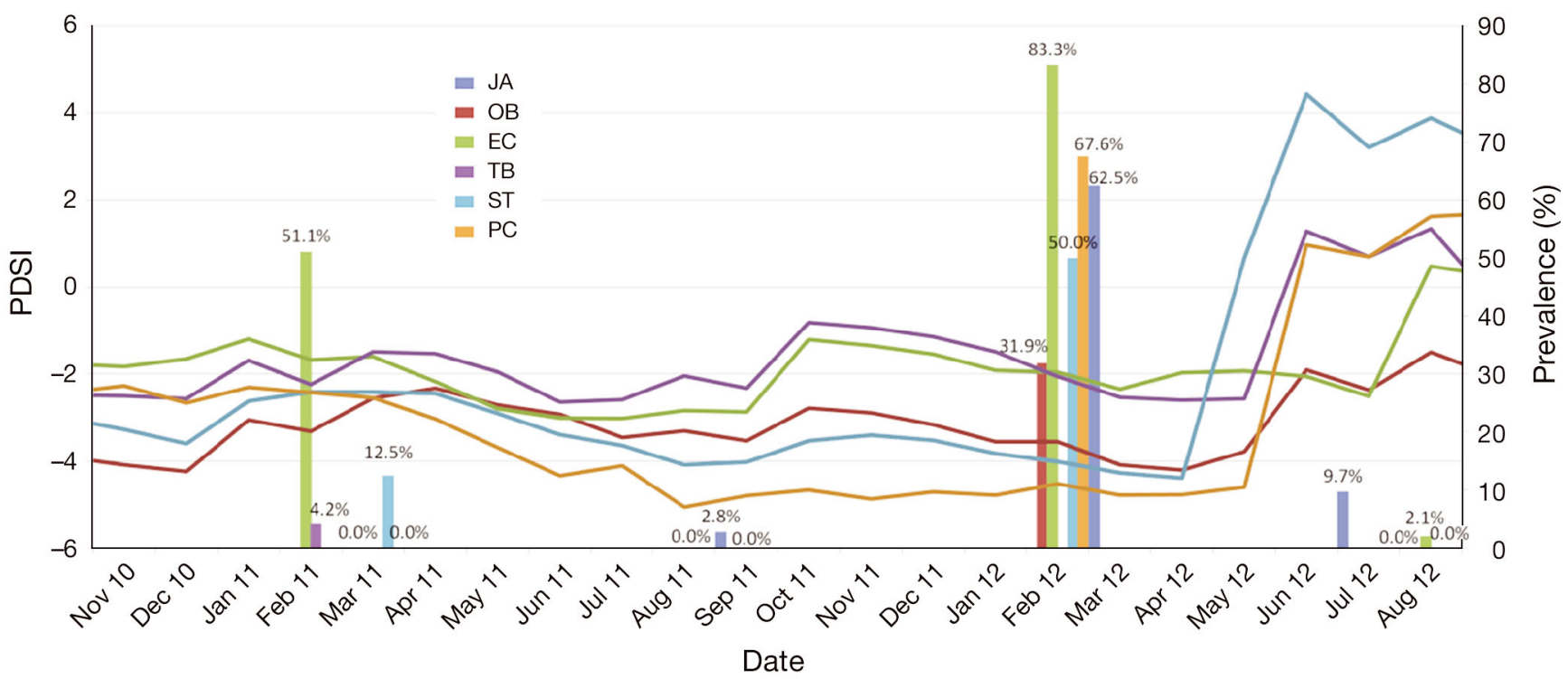

Fig. 3. Prevalence of Hematodinium perezi in samples of blue crabs Callinectes sapidus at sampling sites in Florida, USA (bars), when crab collection occurred, compared with a continuous Palmer Drought Severity Index (PDSI; lines) for the study period. Location abbreviations as in Table 1

turned at most locations: JA (very wet), OB (mild drought), TB (slightly wet), EC (near normal), ST (very wet), PC (slightly wet) (Fig. 2). The impact of drought condition on disease prevalence was not apparent (Fig. 3). Salinity values recorded at the time of sample collection ranged from 1.4 to $36.7 \mathrm{PSU}$, depending on the location and time of year (Table 1). The effect of salinity on prevalence of the parasite in summer or winter samples was not readily apparent (Fig. 4).

Seasonal fluctuations in water temperature are shown in Fig. 5 and were compiled from the nearest NOAA buoys. Winter temperatures were highly dependent on the location, and ranged from 10.9 to $22.1^{\circ} \mathrm{C}$, with the low temperatures occurring in December 2010 and January 2012 at all locations. 

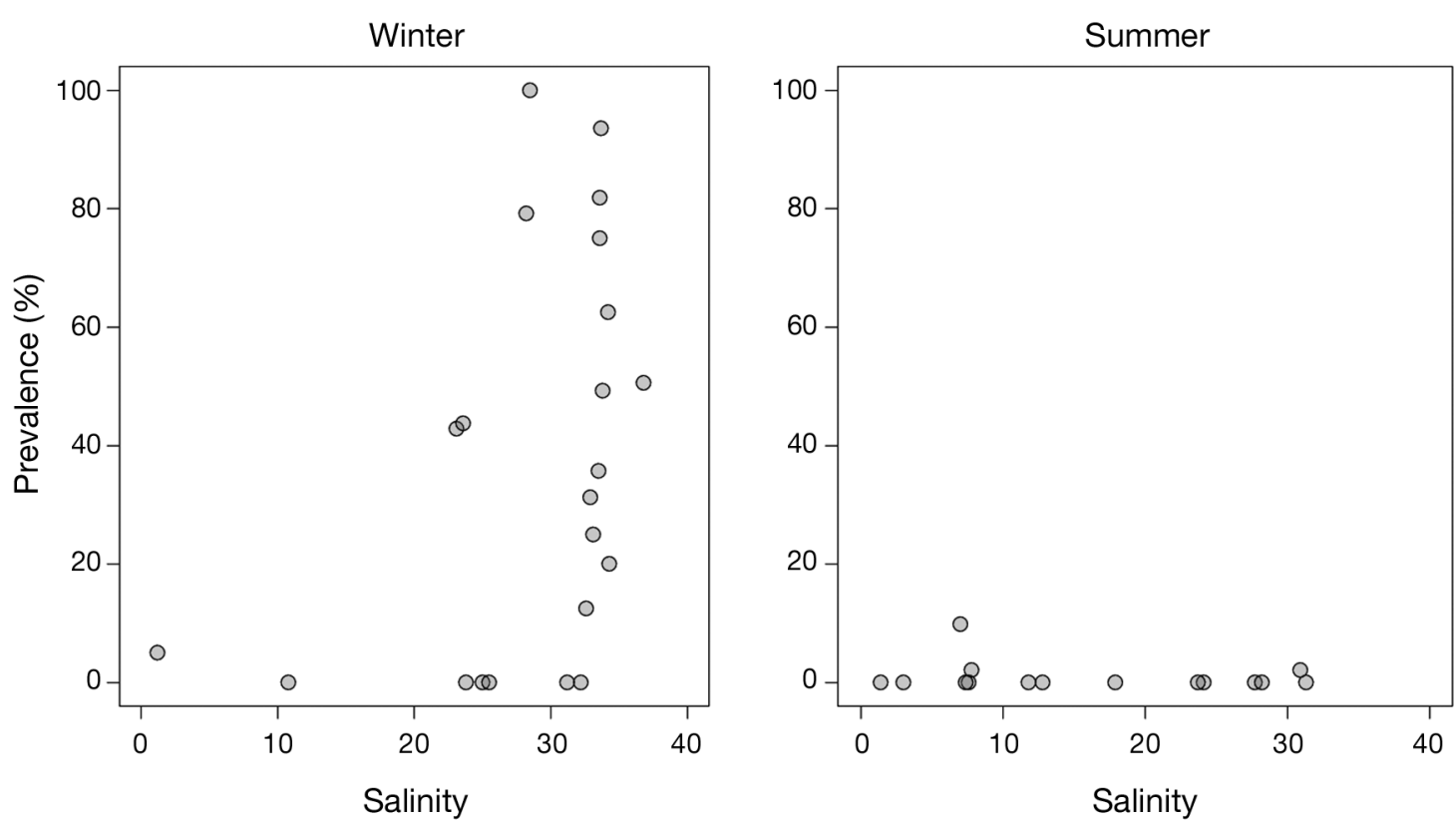

Fig. 4. Seasonal prevalence of Hematodinium perezi in samples of blue crabs Callinectes sapidus at various salinities

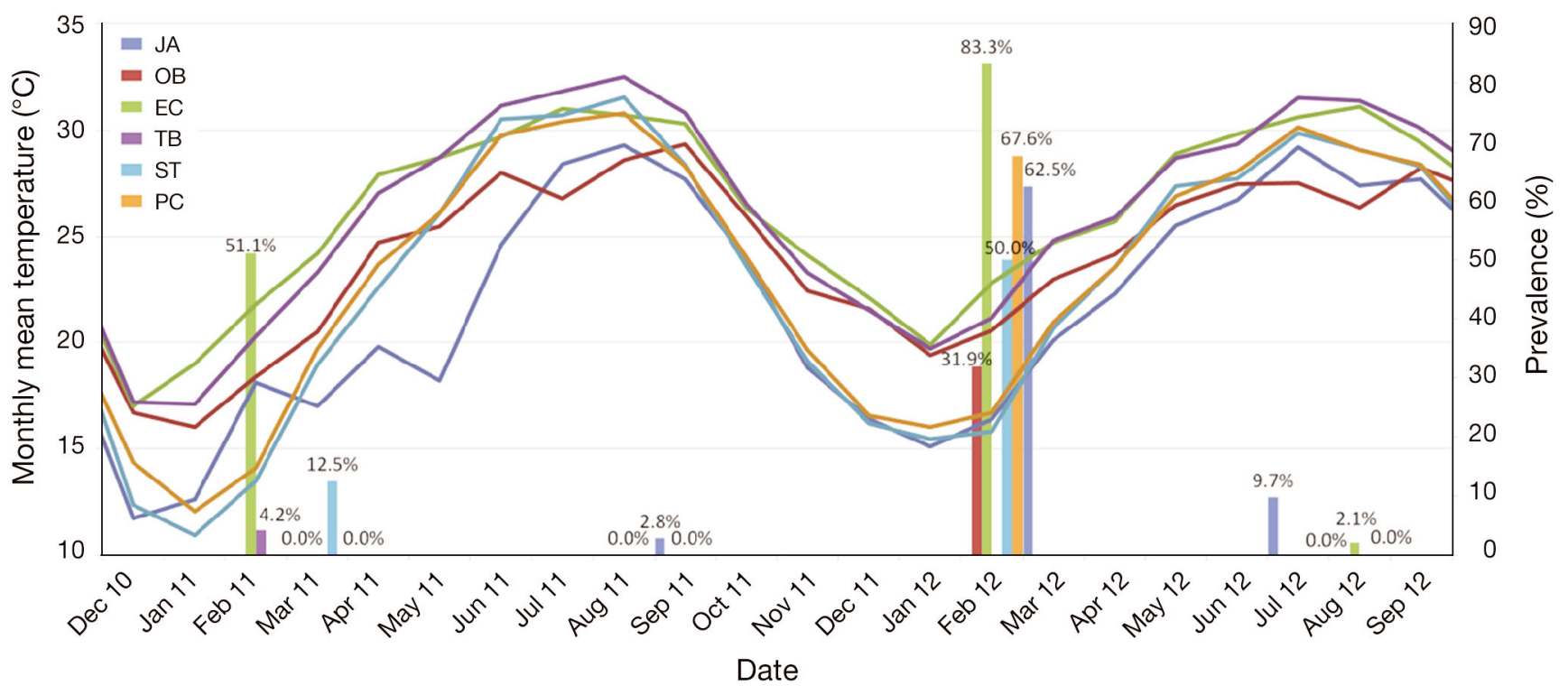

Fig. 5. Prevalence of Hematodinium perezi in samples of blue crabs Callinectes sapidus at sampling sites in Florida, USA (bars), when crab collection occurred, compared with continuous water temperatures (monthly mean of closest NOAA buoy; lines) for the study period. Location abbreviations as in Table 1

Summer high temperatures occurred in August 2011 and 2012 at all locations and ranged from 26.3 to $31.4^{\circ} \mathrm{C}$. Temperature values were recorded at the time of sample collection and ranged from 15.5 to $30.3^{\circ} \mathrm{C}$, depending on the location and time of year (Table 1). Temperature appeared to have an effect on the prevalence of the parasite (Fig. 6).

\section{DISCUSSION}

The 2 yr study presented here provides an assessment of the spatial and temporal distribution of Hematodinium perezi in blue crabs in Florida and fills an important data gap in the assessment of $H$. perezi for the USA. The use of commercial fisher- 

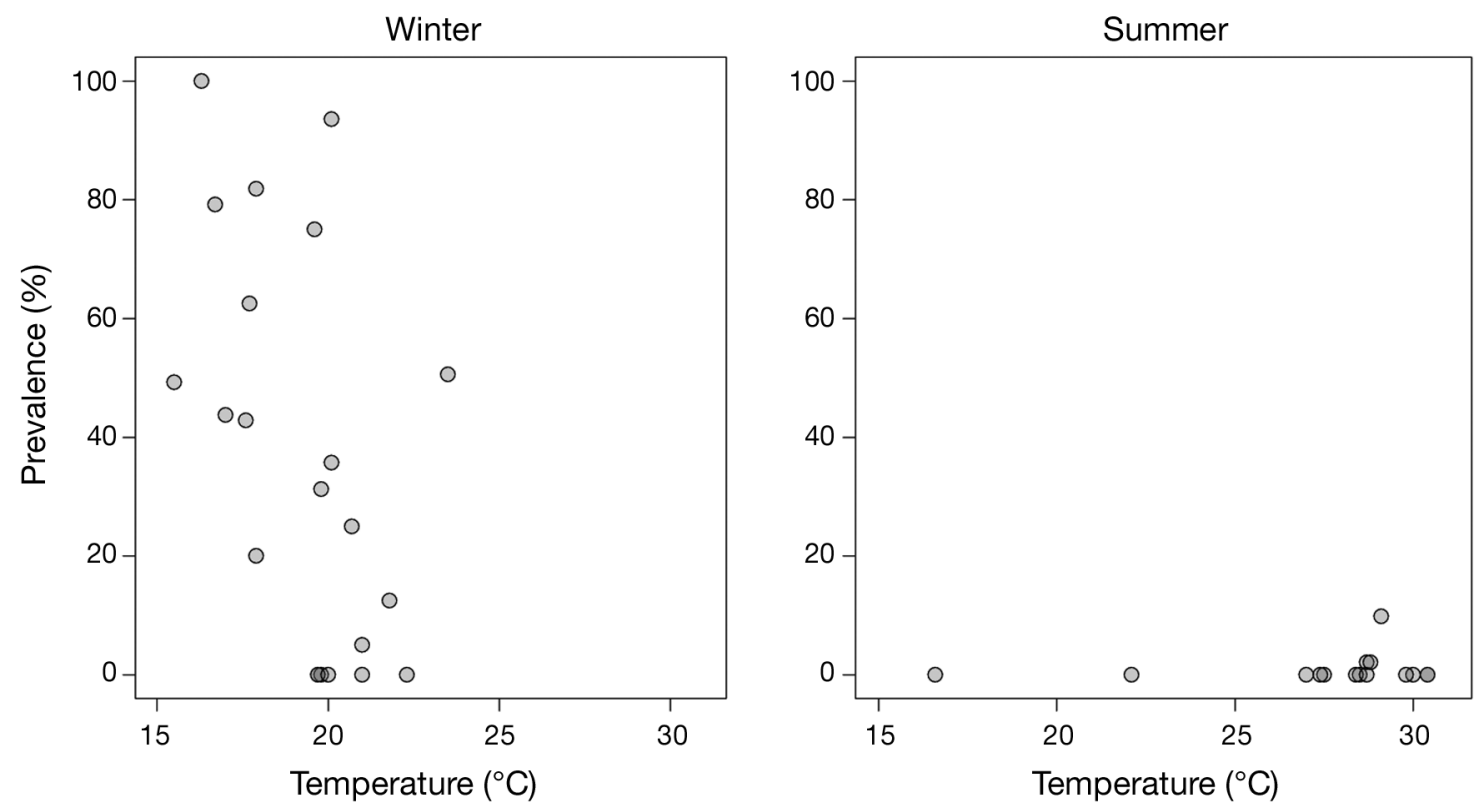

Fig. 6. Prevalence of Hematodinium perezi in samples of blue crabs Callinectes sapidus at various water temperatures in each sampling season

men and their gear to sample blue crabs resulted in a bias toward large or mature crabs that may (Messick 1994, Messick \& Shields 2000) or may not (Parmenter et al. 2013) affect the prevalence found in this study. The overall $H$. perezi prevalence for the $2 \mathrm{yr}$ sampling period was $25.3 \%$ (95\% CI: $22.8-28.1 \%$ ) of the 1066 crabs sampled from 6 locations. Despite drought conditions across Florida during this study, $H$. perezi was not universally found. The majority of the infections occurred in 4 locations (JA, EC, ST, and PC) during winter sampling.

$H$. perezi prevalence in Florida blue crabs was significantly higher during winter $(40.9 \%)$ than summer $(2.11 \%)$ for both study years. The seasonal pattern appeared regardless of coast or latitude, suggesting that seasonality may be a strong factor overriding other environmental drivers, such as drought. The seasonality of prevalence is consistent with other studies of $H$. perezi in Callinectes sapidus, which showed seasonal peaks in prevalence in the spring (April and May) and fall (October and November) in Georgia (Sheppard et al. 2003), and early winter (November and December) in Maryland and South Carolina (Messick \& Shields 2000, Parmenter et al. 2013). In Maryland, South Carolina, and Georgia, H. perezi prevalence was lowest from January through April, whereas in Florida the highest prevalence was observed in February and March samples, and few infections were detected in late summer.
In the present study, at the time of winter sampling in February and March, water temperatures were beginning the seasonal rise from winter lows ranging from 15 to $16^{\circ} \mathrm{C}$. Conversely, in the Maryland, South Carolina, and Georgia studies, peak H. perezi prevalence was observed when water temperatures had recently cooled (e.g. 95\% prevalence in October, at $18^{\circ} \mathrm{C}$; Messick \& Shields 2000) but crabs were still presumably active following the summer season. We hypothesize that $H$. perezi has a temperature optimum of 15 to $18^{\circ} \mathrm{C}$ for either transmission or proliferation in blue crab, meaning that in Maryland, South Carolina, and Georgia, the parasite's proliferation in the blue crab peaks when temperatures cool to $15-16^{\circ} \mathrm{C}$ following the host's summer active period. However, in Florida, where the host is active yearround, the parasite appears to be able to proliferate in the spring, when temperatures rise above $15^{\circ} \mathrm{C}$ but have not yet reached the seasonal apex of $>27^{\circ} \mathrm{C}$.

Our observations and this hypothesis are only partly consistent with in vitro parasite culture work, in which proliferation of $H$. perezi from $C$. sapidus was successfully completed at $15^{\circ} \mathrm{C}$ and $23^{\circ} \mathrm{C}$ but not at $10^{\circ} \mathrm{C}$ (Li et al. 2011). Thus, there may be a low temperature barrier to the proliferation of $H$. perezi in vitro and in the host. Latitudinal or climatic variability may affect the ability of the parasite to proliferate by impacting both the physiology of the parasite and the activity and life history patterns of the blue crab. The results of the present study reiterate that the 
population dynamics of parasitism in aquatic animals are not only a result of the interaction of host and parasite but also depend on environmental factors that can affect host susceptibility, may promote or inhibit parasite proliferation, and influence the abundance of alternate hosts (Snieszko 1974, Pagenkopp Lohan et al. 2012, Pitula et al. 2012).

Parasite prevalence was noticeably higher in 2012 than 2011. In the winter of 2011-2012, we recorded appreciable parasite prevalence (32 to $83 \%$ ) at all sites except TB. The entire state was under drought conditions through the winter of 2011-2012, making it difficult to ascertain whether it was drought conditions that produced elevated $H$. perezi prevalence or local abiotic factors, such as temperature and salinity. It is interesting to note that the Atlantic coast sites, JA and $\mathrm{OB}$, were under greater drought influence than the Gulf coast sites and had similar salinity to EC, yet crabs captured there did not have detectable $H$. perezi in the winter of 2010-2011. This suggests that other local factors or combinations of factors may supersede the influence of regional drought on prevalence of this disease in Florida. The use of the regional drought index for Florida to indicate a greater potential for $H$. perezi infection may not be reliable due the variability of other local factors. A rise from the winter low temperatures during conditions of elevated salinity may be necessary to trigger parasitic outbreaks with high prevalence and intensity, but an increase in salinity alone is not sufficient to trigger an increase in parasite prevalence.

In winter 2010-2011, only EC showed high prevalence, while in winter 2011-2012, crabs at all sites except TB showed prevalence greater than $50 \%$. This indicates that some large-scale factor may influence year-to-year variation and highlights that EC may have some unique environmental attributes that favor $H$. perezi infections. In terms of larger-scale drivers, climatic (temperature and rainfall) factors may affect parasite proliferation as well as timing of blue crab recruitment, juvenile mortality, or migration on both coasts of Florida. The contrast between EC and other sites in the winter 2010-2011 suggests that some facet of this location promotes $H$. perezi infections. While temperature and salinity data do not vary noticeably from those other sites, other factors in EC that may influence the parasitism, such as seasonal migrations, population density, presence of potential intermediate hosts, or hydrographic features need further investigation. Blue crabs in waters with minimal tidal exchange and overlying sediment with high organic content have a higher prevalence of Hematodinium sp. (Messick \& Shields 2000, reviewed by
Stentiford \& Shields 2005, Hanif et al. 2013). Anecdotal observations during sampling at the EC location suggest that this site may meet these criteria.

Although this study has provided the most comprehensive dataset on $H$. perezi thus far for Florida, better understanding of environmental contributions are necessary for the elucidation of the dynamics of $H$. perezi infections in Florida. This could be accomplished through more frequent sampling of blue crabs and recording environmental parameters that may influence parasite and host prevalence and intensity.

Acknowledgements. Funding for blue crab research and monitoring was provided by the State of Florida from commercial crab-trap tag fees. We thank the commercial bluecrab fishermen who participated in this study, staff of the FWRI crustacean research project, the staff of the FWRI genetics laboratory, and the reviewers of this manuscript, who helped in its refinement.

\section{LITERATURE CITED}

Coffey AH, Caiwen L, Shields JD (2012) The effect of salinity on experimental infections of a Hematodinium sp. in blue crabs, Callinectes sapidus. J Parasitol 98:536-542

Cooper W, Gandy RL, Crowley CE (2011) A stock assessment for the blue crab, Callinectes sapidus, in Florida waters through 2011. IHR 2011-FWC/FWRI. Florida Fish and Wildlife Conservation Commission, Fish and Wildlife Research Institute, St. Petersburg, FL

- Gruebl T, Frischer ME, Sheppard M, Neumann M, Maurer AN, Lee RF (2002) Development of an 18S rRNA gene targeted PCR based diagnostic for the blue crab parasite Hematodinium sp. Dis Aquat Org 49:61-70

Guillory V, Perry H, Steele P, Wagner T and others (2001) The blue crab fishery of the Gulf of Mexico, United States: a regional management plan. GSMFC Publication No. 96. Gulf States Marine Fisheries Commission, Ocean Springs, MD

Hanif A, Dyson D, Bowers H, Messick G, Jagus R, Schott E (2013) Variation in temporal and spatial incidence of the crustacean pathogen Hematodinium perezi in environmental samples from Atlantic coastal bays. Aquat Biosyst 9:11

Lee R, Frischer M (2004) The decline of the blue crab: Changing weather patterns and a suffocating parasite may have reduced the numbers of this species along the Eastern Seaboard. Am Sci 92:548-553

> Li C, Miller TL, Small HJ, Shields JD (2011) In vitro culture and developmental cycle of the parasitic dinoflagellate Hematodinium sp. from the blue crab Callinectes sapidus. Parasitology 138:1924-1934

- Messick GA (1994) Hematodinium perezi infections in adult and juvenile blue crabs Callinectes sapidus from coastal bays of Maryland and Virginia, USA. Dis Aquat Org 19: $77-82$

Messick GA, Shields JD (2000) Epizootiology of the parasitic dinoflagellate Hematodinium sp. in the American blue crab Callinectes sapidus. Dis Aquat Org 43:139-152

Nagle L, Place AR, Schott EJ, Jagus R, Messick G, Pitula JS (2009) Real-time PCR-based assay for quantitative detec- 
tion of Hematodinium sp. in the blue crab Callinectes sapidus. Dis Aquat Org 84:79-87

Newman MW, Johnson CA (1975) A disease of blue crabs (Callinectes sapidus) caused by a parasitic dinoflagellate, Hematodinium sp. J Parasitol 61:554-557

Pagenkopp Lohan KM, Reece KS, Miller TL, Wheeler KN, Small HJ, Shields JD (2012) The role of alternate hosts in the ecology and life history of Hematodinium sp., a parasitic dinoflagellate of the blue crab (Callinectes sapidus). J Parasitol 98:73-84

Pagenkopp Lohan KM, Small HJ, Shields JD, Place AR, Reece KS (2013) Conservation in the first internal transcribed spacer (ITS1) region of Hematodinium perezi (genotype III) from Callinectes sapidus. Dis Aquat Org 103:65-75

Parmenter K, Vigueira P, Morlok C, Micklewright J, Smith K, Paul K, Childress M (2013) Seasonal prevalence of Hematodinium sp. infections of blue crabs in three South Carolina (USA) rivers. Estuaries Coasts 36:174-191

Pitula JS, Dyson W, Bakht HB, Njoku I, Chen F (2012) Temporal distribution of genetically homogenous 'free-living' Hematodinium sp. in a Delmarva coastal ecosystem. Aquat Biosyst 8:16

Sheppard M, Walker A, Frischer ME, Lee RF (2003) Histopathology and prevalence of the parasitic dinoflagellate, Hematodinium sp., in crabs (Callinectes sapidus, Calli-

Editorial responsibility: Grant Stentiford, Weymouth, UK nectes similis, Neopanope sayi, Libinia emarginata, Menippe mercenaria) from a Georgia estuary. J Shellfish Res 22:873-880

Small HJ, Shields JD, Reece KS, Bateman K, Stentiford GD (2012) Morphological and molecular characterization of Hematodinium perezi (Dinophyceae: Syndiniales), a dinoflagellate parasite of the harbor crab, Liocarcinus depurator. J Eukaryot Microbiol 59:54-66

Snieszko SF (1974) The effects of environmental stress on outbreaks of infectious diseases of fishes. J Fish Biol 6: 197-208

> Stentiford GD, Shields JD (2005) A review of the parasitic dinoflagellates Hematodinium species and Hematodinium-like infections in marine crustaceans. Dis Aquat Org 66:47-70

Stentiford GD, Neil DM, Atkinson RJA (2001) The relationship of Hematodinium infection prevalence in a Scottish Nephrops norvegicus population to seasonality, moulting and sex. ICES J Mar Sci 58:814-823

VanderKooy S (ed) (2013) Gulf Data, assessment, and review. GDAR 01. Stock assessment report: Gulf of Mexico blue crab. GSMFC Number 215. Gulf States Marine Fisheries Commission, Ocean Springs, MS

Wilber DH (1994) The influence of Apalachicola River flows on blue crab, Callinectes sapidus, in north Florida. Fish Bull 92:180-188

Submitted: August 27, 2014; Accepted: December 16, 2014 Proofs received from author(s): March 20, 2015 